\title{
Hybrid Hosts Based on Sodium Alginate and Porous Clay Heterostructures for Drug Encapsulation
}

\author{
Anda Ionelia Voicu (Mihai) ${ }^{1,2}$, Sorina Alexandra Gârea ${ }^{1,2, *}$, Eugeniu Vasile ${ }^{3}$, Adi Ghebaur ${ }^{1,2}$ and Horia Iovu ${ }^{1,2,4}$ \\ 1 Faculty of Applied Chemistry and Materials Science, University Politehnica of Bucharest, 1-7 Gh. \\ Polizu Street, 011061 Bucharest, Romania; anda.voicu89@gmail.com (A.I.V.); adi.ghebaur@upb.ro (A.G.); \\ horia.iovu@upb.ro (H.I.) \\ 2 Advanced Polymer Materials Group, University Politehnica of Bucharest, 1-7 Gh. Polizu Street, \\ 011061 Bucharest, Romania \\ 3 Department of Science and Engineering of Oxide Materials and Nanomaterials, Faculty of Applied Chemistry \\ and Material Science, University Politehnica of Bucharest, 1-7 Polizu, 011061 Bucharest, Romania; \\ eugeniuvasile@yahoo.com \\ 4 Academy of Romanian Scientists, 54 Splaiul Independentei, 050094 Bucharest, Romania \\ * Correspondence: sorina.garea@upb.ro
}

Citation: Voicu (Mihai), A.I.; Gârea, S.A.; Vasile, E.; Ghebaur, A.; Iovu, H. Hybrid Hosts Based on Sodium Alginate and Porous Clay Heterostructures for Drug Encapsulation. Polymers 2021, 13, 2803. https://doi.org/10.3390/ polym 13162803

Academic Editor: Alejandro Sosnik

Received: 27 July 2021

Accepted: 16 August 2021

Published: 20 August 2021

Publisher's Note: MDPI stays neutral with regard to jurisdictional claims in published maps and institutional affiliations.

Copyright: (c) 2021 by the authors. Licensee MDPI, Basel, Switzerland. This article is an open access article distributed under the terms and conditions of the Creative Commons Attribution (CC BY) license (https:// creativecommons.org/licenses/by/ $4.0 /)$.

\begin{abstract}
In this study, some hybrid materials based on sodium alginate (NaAlg) and porous clay heterostructures (PCHs) were investigated as new hosts for 5-Fluorouracil (5-FU) encapsulation. The hybrid hosts were prepared by ionotropic gelation technique using different concentrations of PCHs $(1,3$, and $10 \mathrm{wt} \%)$ in order to identify the optimal parameters for encapsulation and drug release. The obtained hybrid materials were characterized using FTIR Spectrometry, thermogravimetric analysis (TGA), scanning electron microscopy (SEM), and UV-Vis spectrometry to investigate the interactions of the raw materials involved in the preparation of hybrid hosts, the influence of PCHs concentrations on drug encapsulation efficiency and drug release profile. All the results show that the synthesized hybrid materials were able to load a high amount of 5-FU, the encapsulation efficiency and the release profile being influenced by the concentrations of PCHs.
\end{abstract}

Keywords: hybrids; porous clay heterostructures; sodium alginate; drug; 5-Fluorouracil

\section{Introduction}

Cancer is a leading cause of morbidity and death worldwide, which is characterized by the growth of abnormal cells that multiply uncontrollably and have the capacity to destroy healthy cells [1,2]. Nanotechnology is the most important technology used to identify cancerous cells in the initial stage. Another important aspect of cancer therapy is the development of new materials able to minimize the side effects of therapeutic drugs and also to enhance the efficiency of cancer immunotherapy $[3,4]$.

Fluorouracil (5-fluoro-2,4-pyrimidinedione, 5-FU) is a pyrimidine analog drug widely used in chemotherapy. This type of drug shows an important activity concerning solid tumors encountered in breast, lung, colon, brain tumor, pancreatic, liver, and stomach cancer [5,6]. The 5-FU drug exhibits significant disadvantages such as high toxicity, low light stability, short half-life, and low drug selectivity towards tumors. These disadvantages can be overcome by the development of controlled drug-release systems and through loading the 5-FU drug in inorganic clay and/or biopolymeric systems. Usually, 5-FU is available as an intravenous formulation. This type of administration of 5-FU is associated with different side effects such as psychological stress, hypertrophy, or atrophy, which cause damage in healthy tissues. Moreover, intravenous administration of the drug has been shown to cause severe gastrointestinal, hematological, cardiac, dermatological, and neuronal effects [6-8]. The encapsulation of 5-FU into the host system may reduce the side effects and makes possible its oral administration. 
Natural polymers (polysaccharides, proteins, peptides, polyesters) are materials extensively used in drug delivery systems due to favorable properties such as good biocompatibility and biodegradability, lower toxicity, easy accessibility, the ability to form gels, biological activities, low immunogenicity, low cost, and targeting capacity $[9,10]$. The most widely used natural polymers in drug delivery system are polysaccharides because these materials exhibit an excellent ability to encapsulate various drug molecules and a good capacity to achieve a controlled drug release profile. Polysaccharides can also minimize the side-effects of drugs and enhance the pharmacokinetic profile [11]. They can also improve the stability of drug molecules, decrease the drugs premature degradation and also enhance intracellular penetration [12].

Sodium alginate $(\mathrm{NaAlg})$ is an anionic heteropolysaccharide with a linear structure derived from brown seaweed, The structure of sodium alginate consists from (1-4) linked $\beta$-Dmannuronic acid and $\alpha \mathrm{L}$-guluronic acid monomers. NaAlg is a pure natural biodegradable polymer characterized by attractive properties such as biocompatibility, hydrophilicity, relatively low expense, high swelling capacity, and cell attachment ability. It is also a non-toxic material to the human body [13-22]. Unfortunately, NaAlg presents disadvantages such as a strong hydrophilic character and loss of structural integrity. Additionally, being a $\mathrm{pH}$ sensitive polymer in an acidic environment, it tends to shrink, leading to a reduction of the bead size. This decrease is another drawback because the release of the encapsulated drug in NaAlg is lower in gastric fluid. Moreover, the dissolution of the polymer in basic conditions is another limitation of NaAlg [23]. To overcome the disadvantages of the polymer (Na-Alg) and drug (5-FU) limits, new strategies have been developed to obtained materials with special properties. These involve intercalation and reinforcement of sodium alginate with other polymers (gelatin, polyvinyl alcohol, chitosan [24], carrageenan [25], and pectin [26]) or dispersion of micro- and nano-structures (magnesium aluminum silicate [27] montmorillonite (MMT), [28,29], halloysite (HNT) [30,31], mesoporous silica [32], layered double hydroxide (LDH), rectorite, hydroxyapatite [33], graphene oxide (GO) [34,35], and carbon nanotubes (CNT) [36]) within the polymer matrix.

The biomedical applications of NaAlg include drug delivery vehicles for active pharmaceutical ingredients [37]; excipients (e.g., binders) for preparation of tablets or capsules; scaffolds for cell culture and tissue engineering; and model extracellular matrices for biological studies, drug delivery, and magnetic resonance imaging $[19,38]$.

Recently, hybrid nanoparticles based on NaAlg and organic/inorganic compounds were widely used in drug delivery systems because they improve drug release profile, compatibility, and swelling properties [39-41]. Good biocompatibility, tunable mechanical properties, and easy degradation are extraordinary and versatile properties for pharmaceutical purposes. Additionally, these systems have been synthesized to sustain a suitable amount of the drug without causing toxicity or leading to its effects being below the minimum effective level [42].

First, their small size and large surface lead to a higher absorption capacity of the drug and better drug controlled release compared with large carrier [43]. Second, the nanoparticle surface can be modified by chemical functionalization with various molecules in order to increase the drug absorption and release. Third, the introduction of an inorganic guest such as MMT within the polymer matrix could enhance the stability of the alginate and preserves its original biological function. The physical properties of the alginate beads could be improved by dispersing the magnesium aluminum silicate (MAS) due to the interaction of Na-Alg with silanol groups of MAS [44]. Drug delivery systems (DDS) based on NaAlg- nano-microparticles, composite microparticles, and biodegradable hydrogels are some examples that offer special features such as controlled drug release, improved $\mathrm{pH}$ sensitivity, and improved swelling capacity [32,36,45-47].

Porous clay heterostructures ( $\mathrm{PCHs}$ ) are inorganic materials, prepared for the first time in 1995 by Galarneau et al. [48]. The PCHs synthesis is based on three main steps: (1) intercalation of surfactant (quaternary alkylammonium cations) and co-surfactant (neutral amine) into layered inorganic clay, (2) hydrolysis and condensation of silica precursor 
(tetraethyl orthosilicate) in the clay gallery, and (3) thermal treatment or solvent extraction in order to remove the organic compounds [49-53]. PCHs are innovative materials with versatile properties such as: tunable textural properties (high surface area, microporosity, and mesoporosity) [54-58], high adsorption capacity of volatile organic compounds (VOCs) [59], acidic properties [60], high thermal stability and mechanical strength, catalytic properties [61], and dielectric properties [62,63]. The properties of PCH can be adjusted according to the targeted application. For example, the incorporation of different metals (e.g., Al, Zr) into the silica gallery can improve the thermal stability and increase the surface area and surface acidity. These properties make PCHs an efficient absorbent material for different pollutants (heavy metals, dyes). [64,65].

These versatile properties mean that PCHs can be used in a wide range of applications, such as in adsorbents [66-68], decontamination agents [69], and catalysts [70-73]. A new application of PCHs in the field of drug delivery systems was reported in our previous article [74].

In addition, we reported that the PCHs can be used as a nanofiller for NaAlg based films, inducing an increase of thermal stability and storage modulus [75].

Recently, hybrid beads based on PCHs and Na-Alg were synthesized and tested as adsorbents for volatile organic compounds [76].

In this study, some organic-inorganic hybrid hosts based on NaAlg and PCHs were synthesized and proposed as drug delivery systems for 5-Fluorouracil active substance. The performance of these materials as drug delivery systems may be influenced by the interaction between the components involved in the synthesis and the dispersion degree of PCHs within polymeric matrix, and the release of the drug is strongly influenced by the porous texture of PCHs and PCHs content.

\section{Materials and Methods}

\subsection{Materials}

Alginic acid sodium salt (NaAlg) from brown algae with medium viscosity was supplied from Sigma-Aldrich (St. Louis, MO, USA). Nanofil 116 (MMT-Na), a natural montmorillonite with a cationic exchange capacity (CEC) of $116 \mathrm{mEq} / 100 \mathrm{~g}$ clay was purchased from Southern Clay Products (Gonzales, TX, USA). Hexadecyltrimethylammonium bromide (HDTMA-Br), tetraethyl orthosilicate (TEOS), dodecylamine (DDA), and 5-fluorouracil (5-FU) were provided from Sigma-Aldrich and used as received Figure 1.

\subsection{Synthesis of PCHs}

The PCHs material was synthesized using the method described in our previous paper [54], which involves three main steps: (1) organophilization of montmorillonite raw material, (2) hydrolysis and polycondensation reaction of silica precursor in the presence of organically modified MMT, and (3) the final step focused on thermal treatment of PCHs precursors.

In the first step, $10 \mathrm{~g}$ of MMT were subjected for the swelling process in $900 \mathrm{~mL}$ of demineralized water, and then $6 \mathrm{~g}$ of HDTMA was used as an organic agent to intercalate the swollen clay by cationic exchange reaction. The suspension was maintained for $5 \mathrm{~h}$ at $50{ }^{\circ} \mathrm{C}$ under mechanically stirring, and the final product was washed with water, isolated by centrifugation, and dried at room temperature.

The second step was focused on the synthesis of PCHs precursors using organically modified MMT that was treated with a precise amount of neutral amine (DDA) and silica precursor (TEOS) in the presence of water. The molar ratio used in the PCHs synthesis was 1:20:120 (modified MMT:DDA:TEOS).

The thermal treatment of PCHs precursors involves calcination at $650{ }^{\circ} \mathrm{C}$ for $6 \mathrm{~h}$ in air in order to remove the organic templates. 


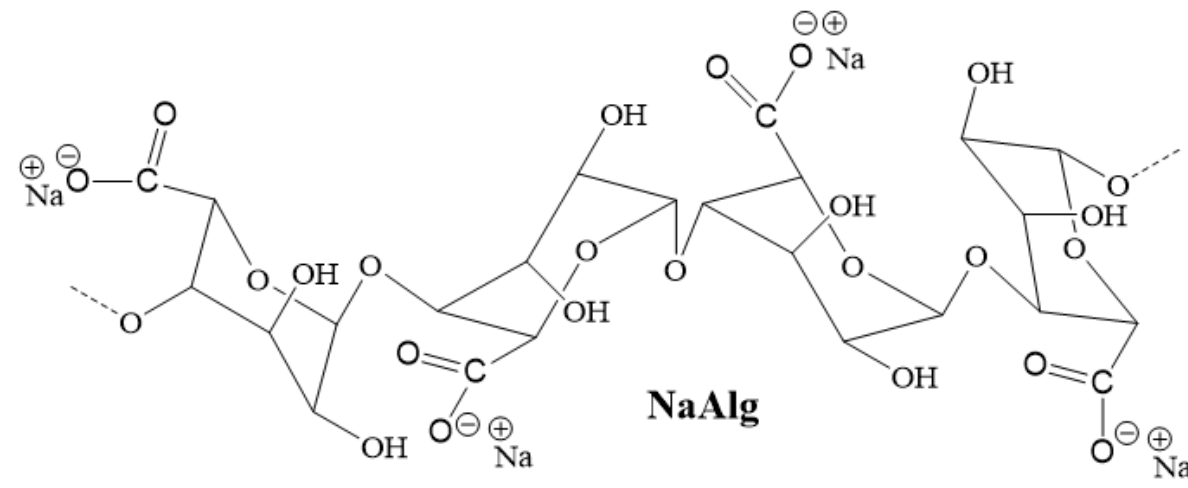

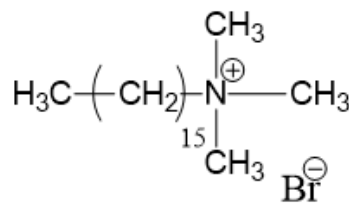

HDTMA-Br-<smiles>CCO[Si](OCC)(OCC)OCC</smiles>

$$
\begin{gathered}
\mathrm{H}_{3} \mathrm{C}-\mathrm{CH}_{2}-\mathrm{CH}_{10}-\mathrm{NH}_{2} \\
\text { DDA }
\end{gathered}
$$<smiles>O=c1[nH]cc(F)c(=O)[nH]1</smiles>

5-FU

Figure 1. Chemical structure of raw materials.

\subsection{Synthesis of Hybrid Beads}

The preparation of hybrid beads based on NaAlg and $\mathrm{PCH}$ was performed using the protocol shown in Figure 2. In the first step, $10 \mathrm{mg}$ of 5-FU were dissolved in $10 \mathrm{~mL}$ of deionized water at room temperature (RT) under magnetic stirring. In the second step, different PCHs concentrations (1, 3, and $10 \mathrm{wt} \%$ ) were dispersed in 5-FU solution under magnetic stirring for $1 \mathrm{~h}$ at RT. Into the obtained suspensions a certain amount of NaAlg was added to achieve $2 \% \mathrm{NaAlg}$ solution, and then the hybrid systems (NaAlg-PCHs-5-FU) were stirred for $24 \mathrm{~h}$ in the absence of light at RT. In the final step, each suspension was dropped into calcium chloride solution $(1 \mathrm{wt} \%)$ in order to obtain the hybrid beads by inotropic gelation. The hybrid beads were maintained in $\mathrm{CaCl}_{2}$ solution for $30 \mathrm{~min}$ and then were collected by filtration. After filtration, the supernatant was used to determine the encapsulation efficiency of 5-FU from hybrid beads. The amount of 5-FU entrapped in the NaAlg-PCHs system was determined using UV-Vis spectrophotometer (Cary 60, Agilent Technologies, Santa Clara, CA, USA) at $\lambda=265 \mathrm{~nm}$. The beads were air dried for further characterization. 


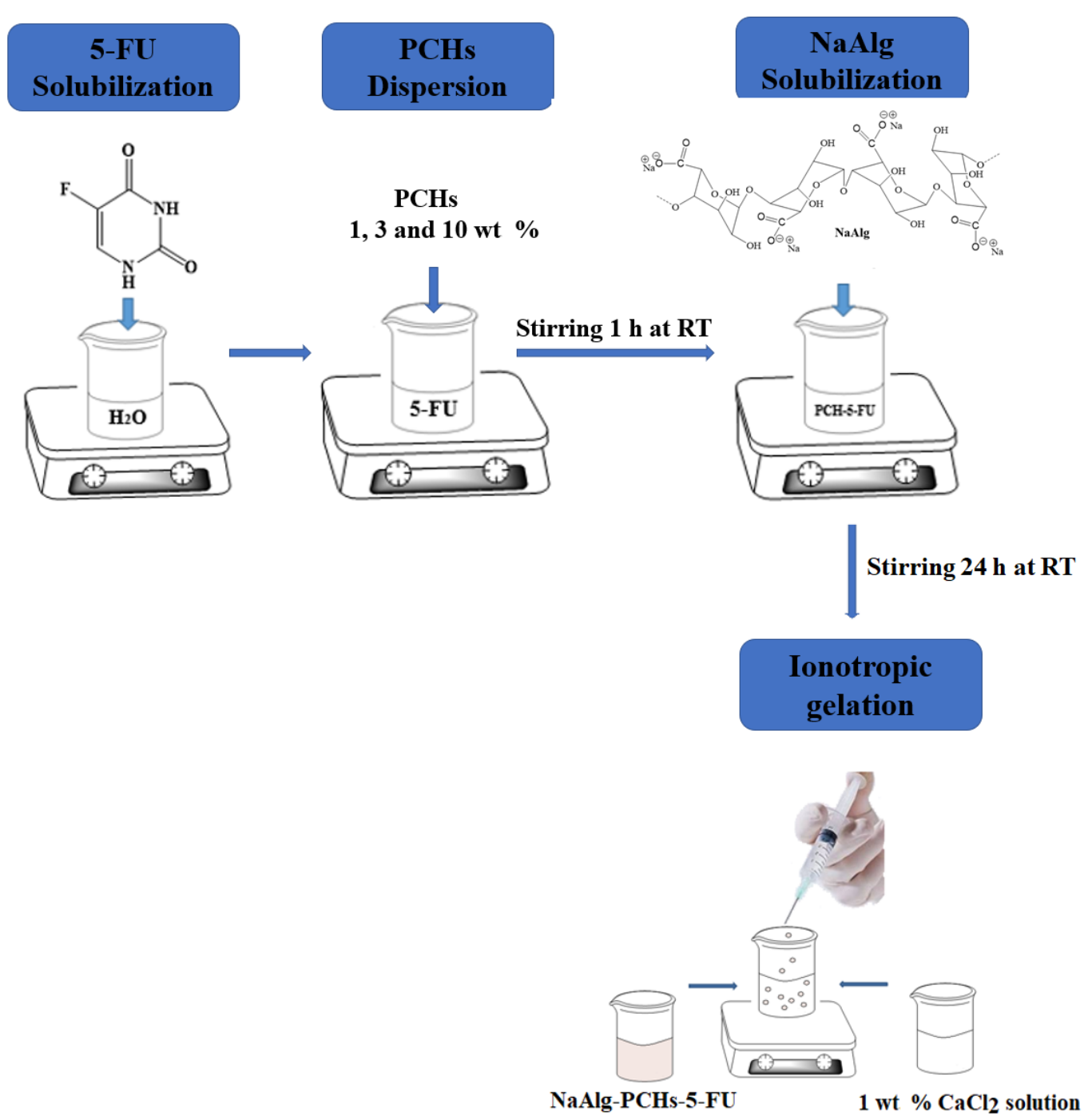

Figure 2. Synthesis steps of hybrid beads.

\subsection{Characterization Techniques}

Fourier Transform Infrared Spectrometry (FTIR) were recorded on an ATR Bruker VERTEX 70 spectrometer (Bruker, Billerica, MA, USA), using 32 scans with a resolution of $4 \mathrm{~cm}^{-1}$ in $4000-600 \mathrm{~cm}^{-1}$ wavenumbers range.

Thermogravimetric analysis (TGA) was done on Q 500 TA Instruments equipment (Bellingham, WA, USA), under inert atmosphere (nitrogen) and a heating rate of $10^{\circ} \mathrm{C} / \mathrm{min}$.

The Quanta Inspect F50 scanning electron microscope (SEM) (FEI, Hillsboro, OR, USA), coupled with energy dispersive X-ray analysis (EDAX, USA), was used to evaluate the morphology of hybrid materials.

The drug encapsulation efficiency and in vitro drug release profiles of 5FU from different hybrid materials was investigated using a UV-Vis spectrophotometer (Cary 60) with a flow cell of $1 \mathrm{~mm}$ and a UV Dissolution software, coupled with a completely automated dissolution bath USP Apparatus 1 (708-DS Agilent, Agilent Technologies, Santa Clara, CA, USA) connected to an auto-controlled multichannel peristaltic pump (801 Agilent, Agilent Technologies, Santa Clara, CA, USA). The samples were put into a dialysis membrane bag with $4 \mathrm{~mL}$ buffer solution and then the samples were immersed in $200 \mathrm{~mL}$ dissolution medium ( $2 \mathrm{~h}$ in SGF and $22 \mathrm{~h}$ in SIF) and spin for $24 \mathrm{~h}$ with $70 \mathrm{rpm}$ at $37^{\circ} \mathrm{C}$. At specific time intervals, the amount of released 5-FU was determined at $\lambda=265 \mathrm{~nm}$. The hybrid hosts based on NaAlg and PCHs were analyzed in triplicate. The dissolution media were used without enzymes. 


\section{Results}

\subsection{Characterization of Hybrid Beads}

\subsubsection{FTIR Analysis}

FTIR analysis was suitable to investigate the presence of clay (PCHs) and the antitumoral drug (5-FU) in the NaAlg beads, as well as to identify the possible interaction established between the components involved in the hybrid beads structures. The FTIR spectra of raw materials ( $\mathrm{NaAlg}, \mathrm{PCHs}$, and 5-FU) and composite beads with various concentrations of PCHs $(1,3$, and $10 \mathrm{wt} \%)$ are shown in Figure 3a,b. The FTIR spectra of 5-FU, NaAlg, and PCHs are similar to the ones reported in the literature $[13,45,59,60,77,78]$. In Table 1 are summarized the spectral assignments for raw materials.

As can be observed from Figure $3 b$, the presence of PCHs and the active substance into the polymeric matrix (NaAlg) was proven through the shifting to a higher value of the following peaks: (1) peak at $3343 \mathrm{~cm}^{-1}$ and (2) peak at $1408 \mathrm{~cm}^{-1}$ from NaAlg spectrum (Figure 3a)
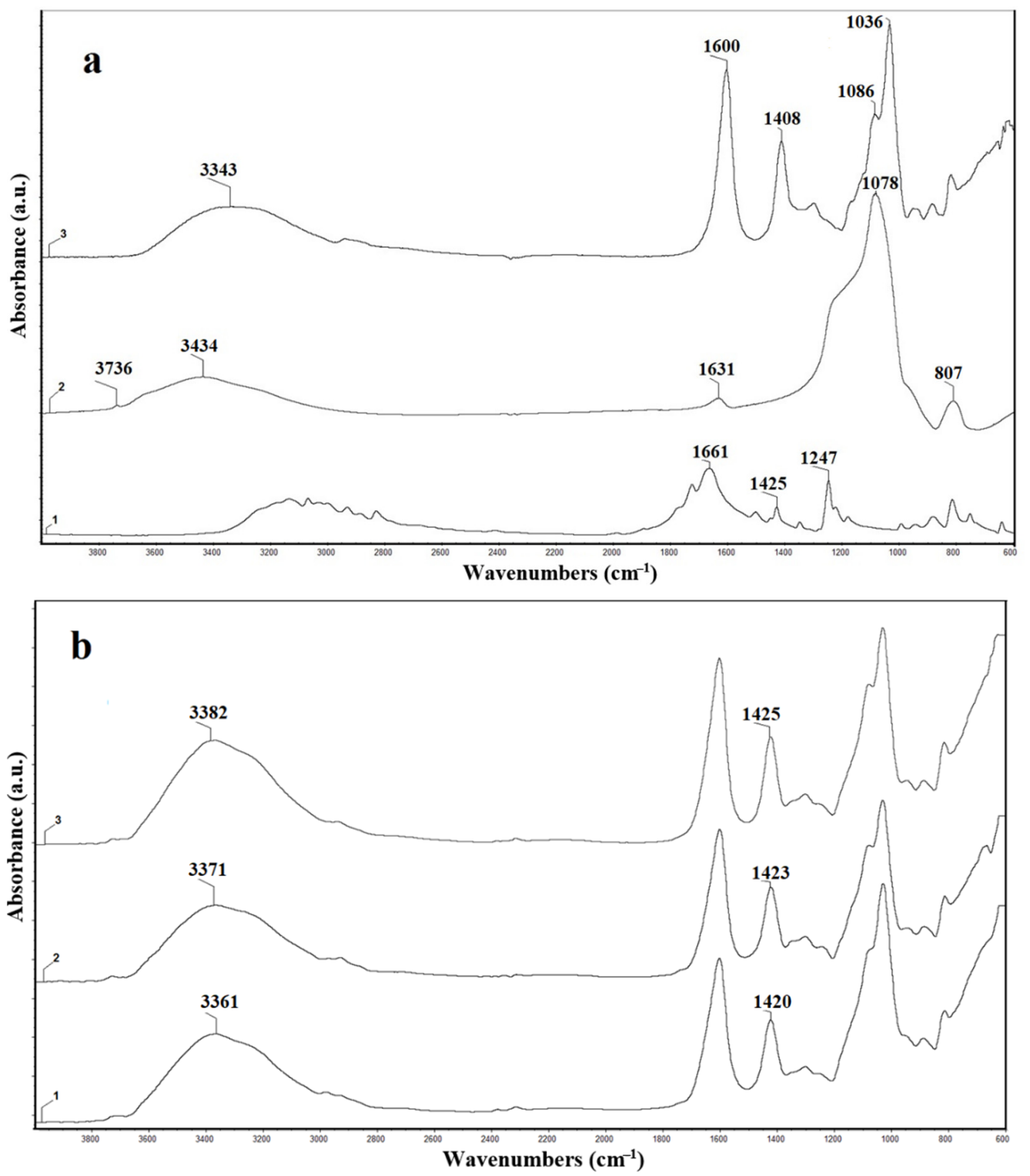

Figure 3. FTIR spectra of: (a): 1- 5-FU, 2-PCHs, 3- NaAlg; (b): 1- NaAlg- 5-FU-PCHs 1 wt\%, 2- NaAlg5-FU-PCHs $3 \mathrm{wt} \%$, 3- NaAlg- 5-FU-PCHs $10 \mathrm{wt} \%$. 
Table 1. Assignment of the characteristic peak of raw materials.

\begin{tabular}{|c|c|c|c|c|c|}
\hline \multicolumn{2}{|c|}{ NaAlg } & \multicolumn{2}{|r|}{$\mathrm{PCH}$} & \multicolumn{2}{|c|}{ 5-FU } \\
\hline $\begin{array}{l}\text { Wavenumber } \\
\left(\mathrm{cm}^{-1}\right)\end{array}$ & Type of vibrations & $\begin{array}{l}\text { Wavenumber } \\
\quad\left(\mathrm{cm}^{-1}\right)\end{array}$ & Type of vibrations & $\begin{array}{l}\text { Wavenumber } \\
\left(\mathrm{cm}^{-1}\right)\end{array}$ & Type of vibrations) \\
\hline 3343 & $\begin{array}{c}\text { Symmetric } \\
\text { stretching vibration } \\
\text { of hydroxyl group } \\
(\mathrm{OH})\end{array}$ & 3736 & $\begin{array}{l}\text { Stretching vibration of } \\
\text { the OH group from } \\
\text { Si-OH }\end{array}$ & 1661 & $\begin{array}{l}\text { Stretching vibration } \\
\qquad \mathrm{C}=\mathrm{C} \\
\text { Stretching vibration of } \\
\text { carbonyl group }(\mathrm{C}=\mathrm{O})\end{array}$ \\
\hline 1600 & $\begin{array}{c}\text { Symmetric } \\
\text { stretching vibration } \\
\text { of carboxylate group } \\
\left(\mathrm{COO}^{-}\right)\end{array}$ & 3434 & $\begin{array}{l}\text { Stretching vibration of } \\
\text { the OH group of water } \\
\text { molecules adsorbed on } \\
\text { PCH }\end{array}$ & 1425 & $\begin{array}{l}\text { Bending vibration of } \\
\qquad \mathrm{N}-\mathrm{H}\end{array}$ \\
\hline 1408 & $\begin{array}{c}\text { Asymmetric } \\
\text { stretching vibration } \\
\text { of carboxylate group } \\
\left(\mathrm{COO}^{-}\right)\end{array}$ & 1631 & $\begin{array}{l}\text { Bending vibration of } \\
\text { adsorbed water } \\
\text { molecules }\end{array}$ & 1247 & $\begin{array}{l}\text { Stretching vibration of } \\
\text { the aromatic ring }\end{array}$ \\
\hline $\begin{array}{l}1086 \\
1036\end{array}$ & $\begin{array}{l}\text { Stretching vibration } \\
\text { of } \mathrm{C}-\mathrm{O}-\mathrm{C}\end{array}$ & 1078 & $\begin{array}{l}\text { Stretching vibrations } \\
\text { of three dimensional } \\
\text { silica network }\end{array}$ & - & - \\
\hline- & - & 807 & $\begin{array}{l}\text { Symmetric stretching } \\
\text { vibrations of } \\
\text { Si-O-Si } \\
\text { or } \\
\text { Si-O-Al }\end{array}$ & - & - \\
\hline
\end{tabular}

The presence of the inorganic component $(\mathrm{PCHs})$ into the polymeric matrix $(\mathrm{NaAlg})$ induces a shifting of the peak from $3343 \mathrm{~cm}^{-1}$ to a higher value $\left(3361 / 3371 / 3382 \mathrm{~cm}^{-1}\right)$, which can be attributed to some physical interaction between NaAlg and PCHs (e.g., hydrogen bonding formation). Additionally, the FTIR data indicate that the shifting of this peak is significantly influenced by the PCHs concentration. The highest peak shifting was registered for hybrid materials with $10 \mathrm{wt} \% \mathrm{PCHs}$.

The presence of the active substance (5-FU) into the hybrid materials (NaAlg-PCHs) was highlighted by shifting the peak from $1408 \mathrm{~cm}^{-1}$ for NaAlg to higher values for hybrid materials (e.g., $1425 \mathrm{~cm}^{-1}$ for NaAlg-PCHs $10 \mathrm{wt} \%$ ).

\subsubsection{TGA Tests}

TGA tests were performed to demonstrate the presence of PCHs in drug loaded hybrid beads. PCHs material exhibits a different thermal degradation profile [74], characterized by a higher thermal stability, and therefore the hybrid materials based on the NaAlg matrix and PCHs exhibited different thermal properties depending on PCHs content. As shown in Figure 4 and Table 2, the presence of PCHs was confirmed by the increase of thermal stability of the drug loaded hybrid beads.

All the hybrid materials exhibit a similar TG profile to the 5-FU loaded NaAlg beads, but the presence of PCHs induces a barrier effect, and therefore a slight increase of degradation temperatures $\left(\mathrm{T}_{\mathrm{d} 15 \%}\right.$ and $\mathrm{T}_{\mathrm{d} 40 \%}$ ) was recorded. This effect was mainly observed for hybrids beads with high content of PCHs (10 wt \%).

A similar trend was also observed by other authors for various materials based on $\mathrm{NaAlg}$ and different nanostructured agents such as graphene oxide (GO), Na-montmorillonite, and layered double hydroxide (LDH) [34,79,80]. 


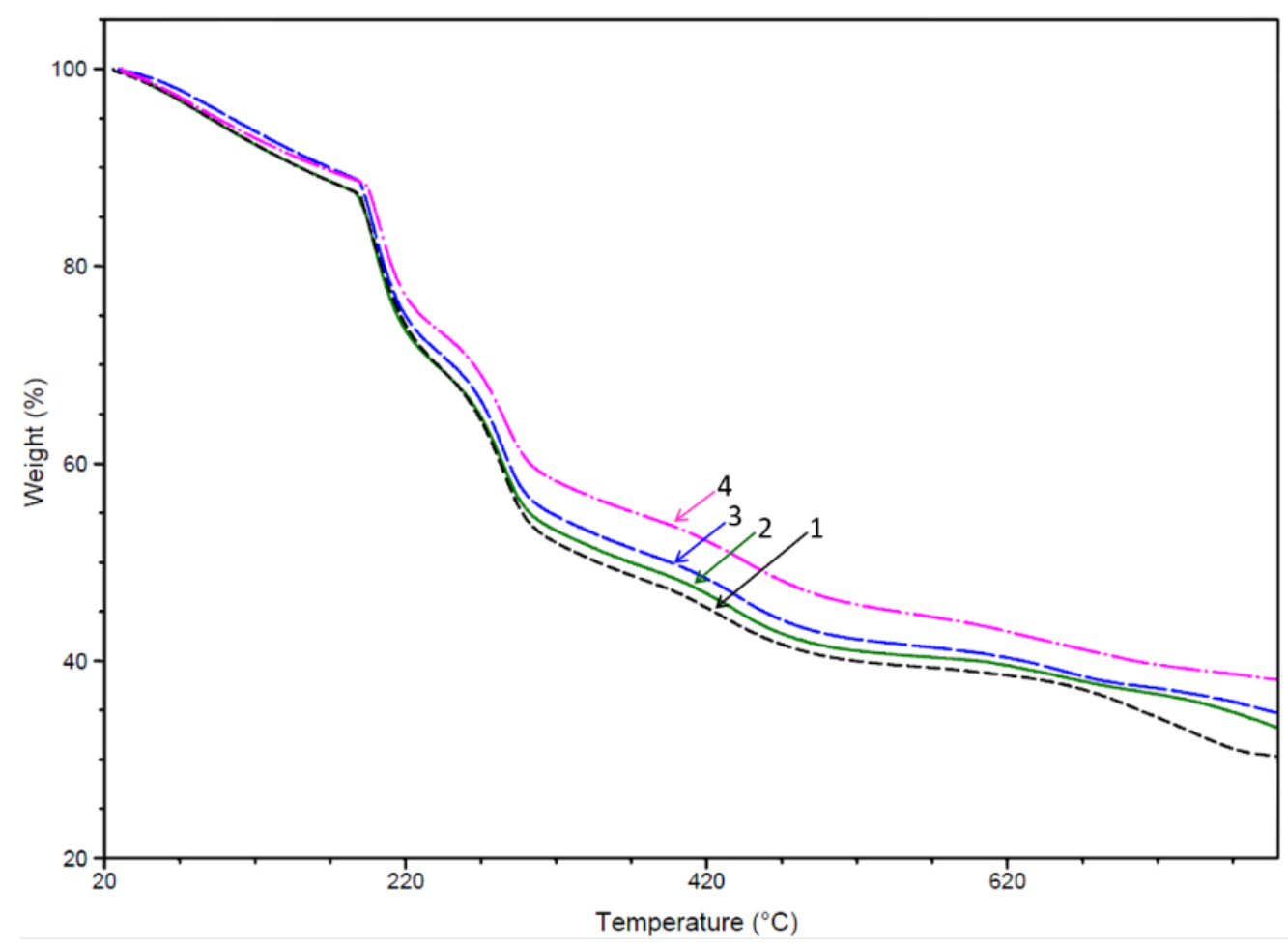

Figure 4. TGA curves of 1-NaAlg-5-FU, 2-NaAlg-5-FU-PCHs 1 wt $\%$, 3-NaAlg-5-FU-PCHs 3 wt $\%$, 4-NaAlg-5-FU-PCHs $10 \mathrm{wt} \%$.

Table 2. Thermal properties of hybrid beads.

\begin{tabular}{|c|c|c|}
\hline Sample & $\mathrm{T}_{\mathrm{d} 15 \%}\left({ }^{\circ} \mathrm{C}\right) *$ & $\mathrm{~T}_{\mathrm{d} 40 \%}\left({ }^{\circ} \mathrm{C}\right) * *$ \\
\hline NaAlg-5-FU & 194 & 284 \\
\hline NaAlg-5-FU-PCHs 1 wt\% & 194 & 285 \\
\hline NaAlg-5-FU-PCHs 3 wt\% & 196 & 287 \\
\hline NaAlg-5-FU-PCHs 10 wt $\%$ & 201 & 303 \\
\hline
\end{tabular}

\subsubsection{SEM Characterization}

SEM analysis was employedto investigate the surface morphology of hybrid beads (Figure 5).

The SEM micrographs reveal that dried hybrid beads based on NaAlg and PCHs were characterized by a rough surface with visible wrinkles and a spherical shape after drying. The SEM images of NaAlg beads indicate a smooth surface that suggests the presence of a uniform structure. The uniform dispersion of $\mathrm{PCHs}$ into the core structure of hybrid beads was highlighted by the SEM results. Even at high PCHs concentrations (10 wt\%), the clay did not exhibit a tendency to form clusters.

Similar results were reported for the hybrid systems alginate/bentonite/imidacloprid [81] and alginate/montmorillonite/curcumin [82].

Energy dispersive X-ray spectroscopy (EDAX) is a useful method to confirm the presence of PCHs in the NaAlg matrix. The EDAX spectrum of PCHs confirms the presence of characteristic signals such as $\mathrm{Si}$ and $\mathrm{O}$, which are the major elements of the clay (Figure 6a).The neat NaAlg hydrogel exhibits the characteristic peaks of a crosslinked network $(\mathrm{Ca}, \mathrm{Cl})$ (Figure 6b).

The EDAX spectra of hybrid beads (Figure 6c) based on NaAlg and PCHs show the presence of peaks assigned for $\mathrm{Si}$ and $\mathrm{Al}$ atoms, which confirmed the presence of $\mathrm{PCH}$ in the polymer. 

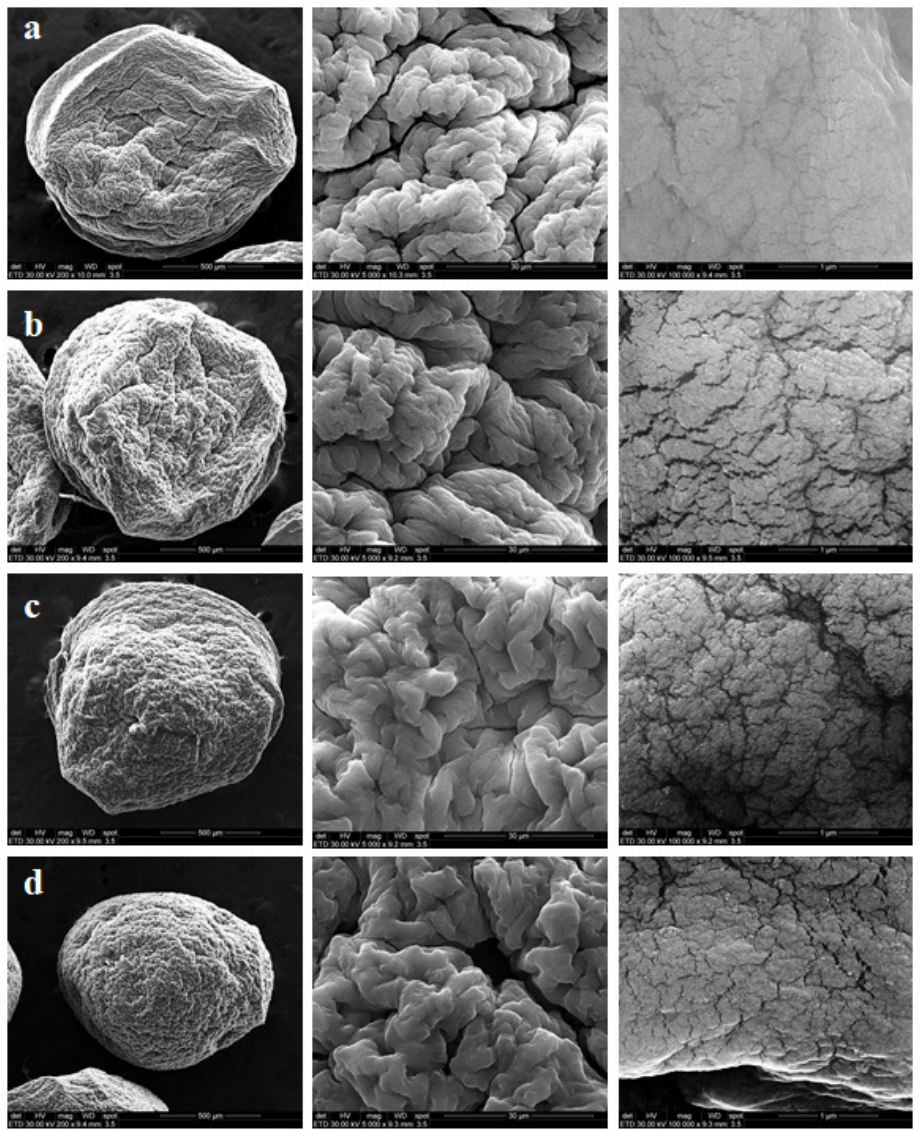

Figure 5. SEM images of the beads with different PCHs concentrations: (a) neat $\mathrm{NaAlg}$, (b) $1 \mathrm{wt} \%$, (c) $3 \mathrm{wt} \%$, and (d) $10 \mathrm{wt} \%$.
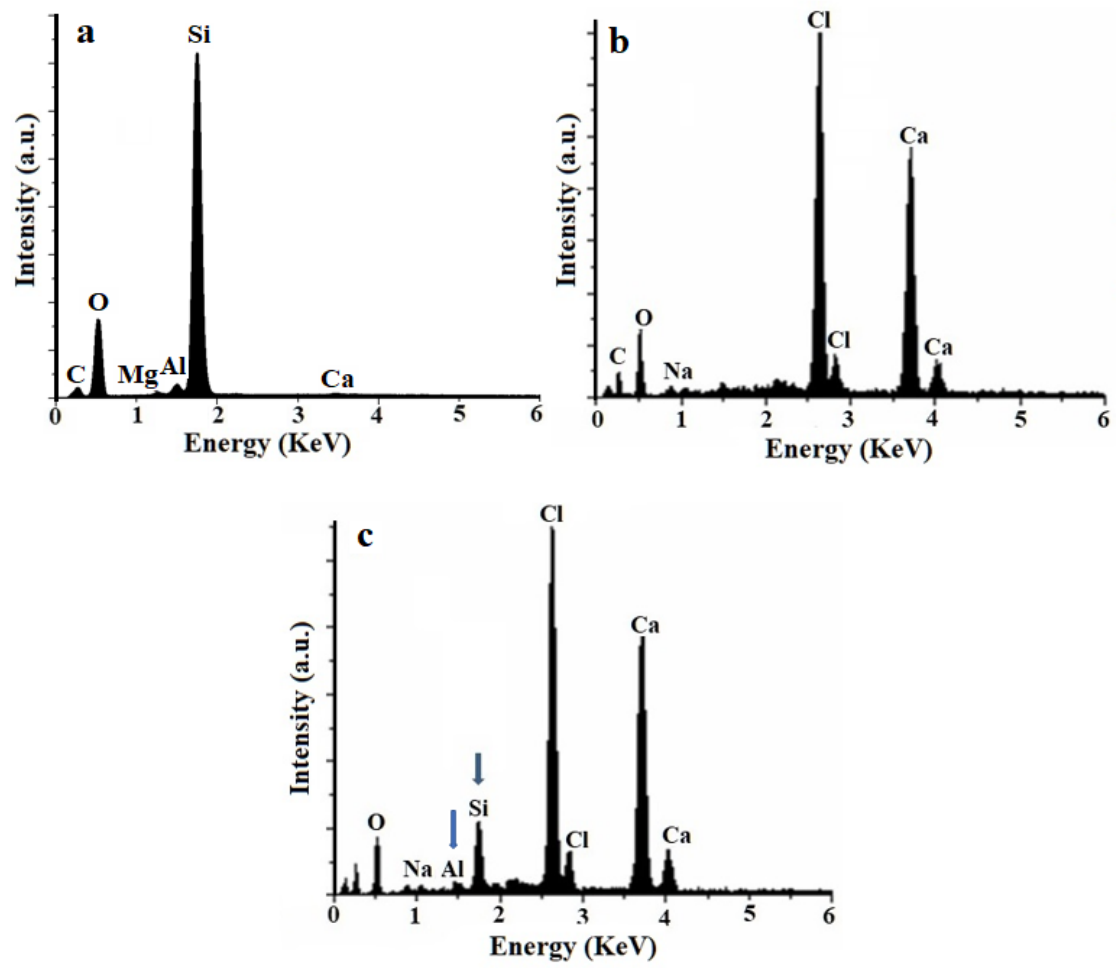

Figure 6. EDAX spectra for: (a) PCHs, (b) Neat NaAlg beads, and (c) hybrid materials NaAlg-PCHs $10 \mathrm{wt} \%$. 


\subsubsection{Determination of the Encapsulation Efficiency and Drug Release Profile}

Encapsulation efficiency of 5-FU and the amount of 5-FU released from the hybrid beads systems based on NaAlg and PCHs were determined using the UV-Vis method.

The 5-FU encapsulation efficiency was calculated using Equation (1).

$$
E E(\%)=\frac{W_{\text {total } 5-\mathrm{FU}}-W_{\text {free } 5-\mathrm{FU}}}{W_{\text {total } 5 \text {-FU }}} \times 100
$$

where $W_{\text {total 5-FU }}$ is the initial 5-FU amount and $W_{\text {free 5-FU }}$ is the unloaded 5-FU amount.

The UV-Vis results confirmed the PCHs influence in the NaAlg beads. The PCHs concentration influences the encapsulation efficiency $(E E \%)$ and release profile of 5-FU from hybrid beads.

As shown in Table 3, the values of drug EE registered for hybrid beads (NaAlg-PCHs) that contain different concentrations of PCHs $(1,3,10 \mathrm{wt} \%)$ are significantly changed.

Table 3. 5-FU encapsulation efficiency (EE, \%) of neat NaAlg beads and hybrid beads.

\begin{tabular}{cc}
\hline Sample & $\boldsymbol{E E}, \boldsymbol{\%}$ \\
\hline NaAlg-5-FU & 60 \\
NaAlg-5-FU-PCHs 1 wt $\%$ & 70 \\
NaAlg-5-FU-PCHs 3 wt $\%$ & 70 \\
NaAlg-5-FU-PCHs 10 wt $\%$ & 70 \\
\hline
\end{tabular}

The presence of PCHs induces a noticeable increase of $E E$ by comparing with the NaAlg-5-FU. The lowest drug EE value was recorded for the neat NaAlg beads (60\%), and the hybrid beads (NaAlg-5-FU-PCHs-1, 3, $10 \mathrm{wt} \%$ ) exhibit a higher 5-FU encapsulation efficiency $(70 \%)$. This fact can be attributed to the properties of $\mathrm{PCHs}$ (textural properties, large surface area, high porosity, and noticeable adsorbent capacity), which highlights the importance of PCHs for the increase of drug encapsulation efficiency.

In these hybrid beads, two types of interactions play a crucial role on the drug release profile. These interactions are schematically described in Figure 7 and include: (1) polymerdivalent cation interaction and (2) clay-divalent cation interaction.

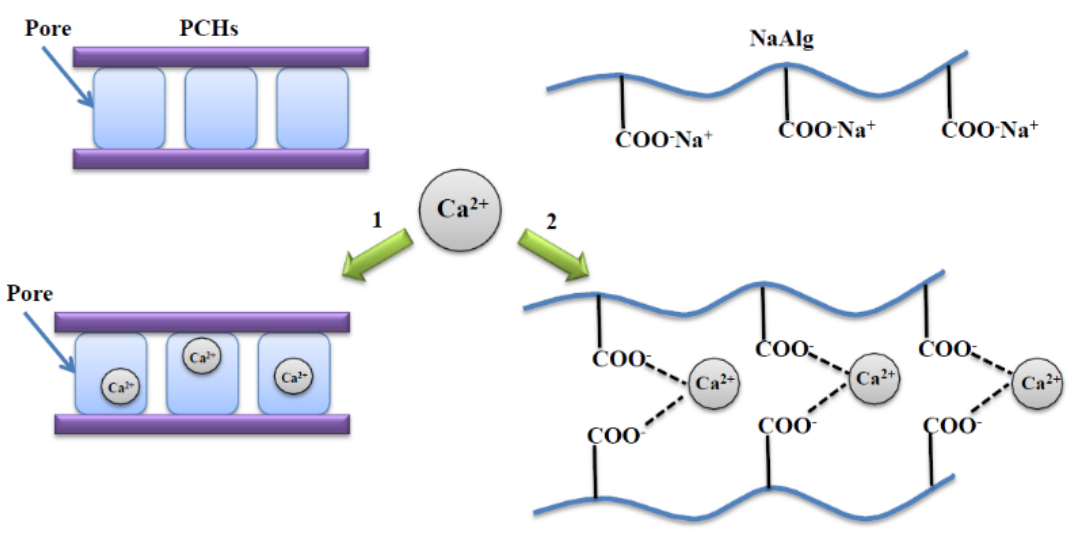

Figure 7. Possible interaction of NaAlg and $\mathrm{PCHs}$ with divalent cation $\left(\mathrm{Ca}^{2+}\right)$ in ionotropic gelation process.

$\mathrm{PCHs}$ can adsorb $\mathrm{Ca}^{2+}$ ions into the porous structure, and therefore a significant decrease of $\mathrm{CaCl}_{2}$ solution concentration involved in the ionotropic gelation process occurs. The high adsorption capacity of PCHs has also been reported in the literature [69].

The release profiles of 5-FU from hybrid materials in SIF and SGF are presented in Figure 8. 


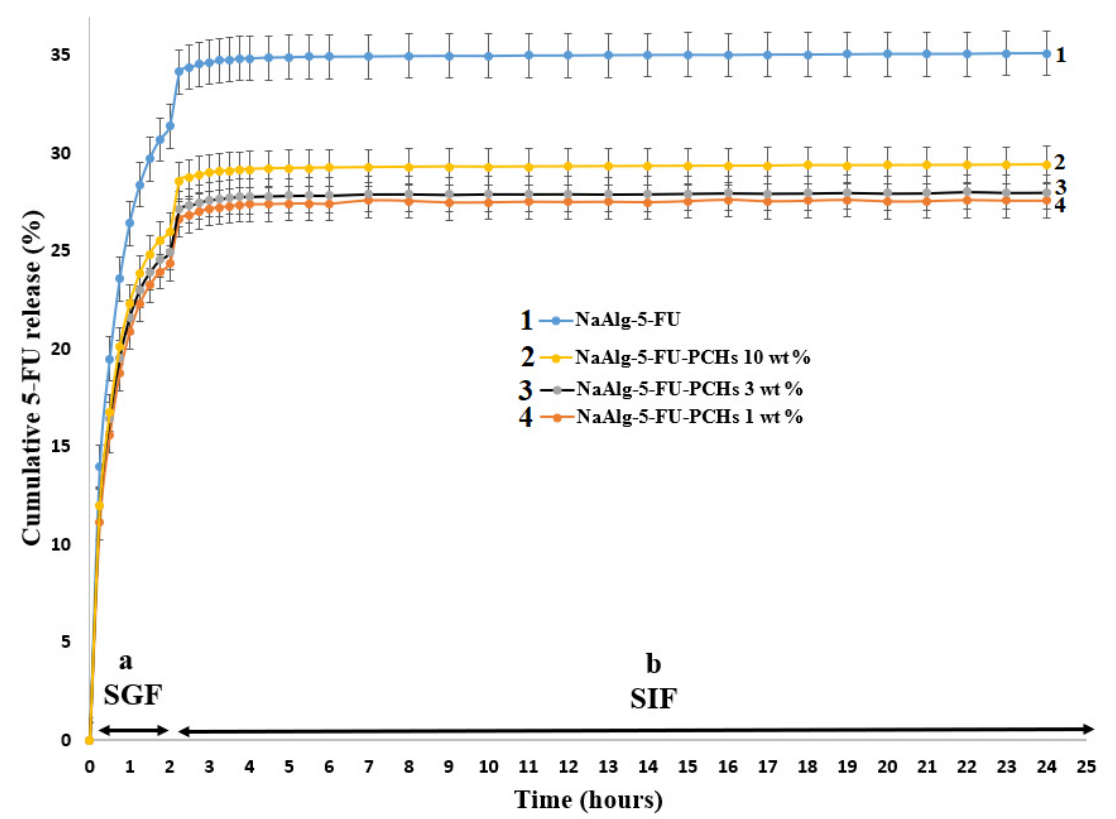

Figure 8. Drug release profiles in SGF (a) and SIF (b) for: 1-NaAlg-5-FU, 2-NaAlg-5-FU-PCHs 10 wt $\%$, 3-NaAlg-5-FU-PCHs $3 \mathrm{wt} \%$, 4-NaAlg-5-FU-PCHs $1 \mathrm{wt} \%$.

As can be observed in Figure 8, the drug release profile can be influenced with the increase of PCHs concentration. In both SGF and SIF, the highest amount of drug release is registered for NaAlg-5-FU (35\%), followed by NaAlg-5-FU-PCHs $10 \mathrm{wt} \%$ (29\%), NaAlg5 -FU-PCHs $3 \mathrm{wt} \%$ (28\%), and then NaAlg-5-FU-PCHs $1 \mathrm{wt} \%(27 \%)$. The drug release concentration decreases with the decrease of $\mathrm{PCHs}$ amount. This may be caused by the possibility that $\mathrm{PCHs}$ adsorbs a part of the $\mathrm{Ca}^{2+}$ ions, and therefore the final structure of the beads was affected. In addition, the presence of a high PCHs content $(10 \mathrm{wt} \%)$ into $\mathrm{NaAlg}$ beads induces a structure with a high porosity that allows an easier diffusion of drug molecules through the polymer matrix. In the SGF $(\mathrm{pH}=1.2)$, the hybrid beads present a progressive release of 5-FU, and in SIF a linear release of 5-FU was recorded. This may be attributed to the sensitivity of $\mathrm{NaAlg}$ to $\mathrm{pH}$ changes [83].

These results suggest that the presence of PCHs into NaAlg induced a decrease of 5-FU release from hybrid beads and also induce a decrease of the NaAlg hydrogel burst release issue. This phenomenon can be attributed to the barrier effect of PCHs. Similar results were reported for sodium alginate/layered double hydroxides/diclofenac [84].

\section{Conclusions}

New hybrid materials with potential applications in cancer therapy were successfully prepared. These materials, based on NaAlg and PCHs, can be considered as possible hybrid host candidates for 5-FU encapsulation.

The presence of $\mathrm{PCH}$ inorganic nanomaterial, characterized by a high specific surface area, high porosity, and good adsorption capacity within $\mathrm{NaAlg}$ beads strongly influenced the 5-FU encapsulation efficiency, and the drug release profile can be adjusted by using different $\mathrm{PCHs}$ concentration. The burst release can be significantly diminished by adding lower PCHs concentrations (1 wt\%). The hybrids that include higher PCHs content (10 wt \%) are characterized by a faster drug release rate.

All the results proved that the hybrid materials based on NaAlg and PCHs exhibit superior properties compared to the neat classical NaAlg beads for the encapsulation and release of 5-FU. 
Author Contributions: Conceptualization, A.I.V. and S.A.G.; methodology, S.A.G. and A.I.V.; investigation, A.I.V., S.A.G., A.G., and E.V.; resources, S.A.G.; writing-original draft preparation, A.I.V., S.A.G., A.G. and H.I.; writing-review and editing, A.I.V., S.A.G., A.G., and H.I.; supervision, S.A.G. and H.I. All authors have read and agreed to the published version of the manuscript.

Funding: The authors acknowledge the Executive Agency for Higher Education, Research, Development, and Innovation Funding (UEFISCDI), and the National Research Council (CNCS) for financial support for the PN II research project: DRUG DELIVERY HYBRIDS BASED ON POLYMERS AND POROUS CLAY HETEROSTRUCTURES (DELPOCLAY), No. 154/2012.

Institutional Review Board Statement: Not applicable.

Informed Consent Statement: Not applicable.

Data Availability Statement: Not applicable.

Acknowledgments: The authors acknowledge the support of PubArt Programme from University Politehnica of Bucharest.

Conflicts of Interest: The authors declare no conflict of interest.

\section{References}

1. Taleuzzaman, M.; Gupta, D.K.; Kala, C.; Gilani, S.J.; Beg, S. Chapter 12-Nanotechnology-assisted medical devices in cancer treatment. In Nanoformulation Strategies for Cancer Treatment; Micro and Nano Technology; Elsevier: Amsterdam, The Netherlands, 2021; pp. 195-205. [CrossRef]

2. Solhjoo, A.; Sobhani, Z.; Sufali, Z.; Rezaei, Z.; Khabnadiedeh, S.; Sakhteman, A. Exploring pH dependent delivery of 5-fluorouracil from functionalized multi-walled carbon nanotube. Colloids Surf. B Biointerfaces 2021, 205, 111823. [CrossRef]

3. Zeng, Y.; Xiang, Y.; Sheng, R.; Tomas, H.; Rodrigues, J.; Gu, Z.; Zang, H.; Gong, Q.; Luo, K. Polysaccharide-based nanomedicine for cancer immunotherapy: A review. Bioact. Mater. 2021, 6, 3358-3382. [CrossRef]

4. Lu, L.; Sun, Y.; Wan, C.; Hu, Y.; Lo, P.-C.; Lovell, J.F.; Yang, K.; Jin, H. Role of intravital imaging in nanomedicine assisted anti-cancer therapy. Curr. Opin. Biotech. 2021, 69, 153-161. [CrossRef]

5. Nagarwal, R.C.; Kumar, R.; Pandit, J.K. Chitosan coated sodium alginate-chitosan nanoparticles loaded with 5-FU for ocular delivery: In Vitro characterization and In Vivo study in rabbit eye. Eur. J. Pharm. Sci. 2012, 47, 678-685. [CrossRef]

6. Azhar, F.; Olad, F.; Olad, A. A study on sustained release formulations for oral delivery of 5-fluorouracil based on alginatechitosan/montmorillonite nanocomposite systems. Appl. Clay Sci. 2014, 101, 288-296. [CrossRef]

7. Arias, J.L. Nouvel strategies to improve the anticancer action of 5-fluorouracil by using drug delivery systems. Molecules 2008, 13, 2340-2369. [CrossRef]

8. Puga, A.M.; Limab, A.C.; Manob, J.F.; Concheiroa, A.; Alvarez-Lorenzoa, C. Pectin-coated chitosan microgels crosslinked on superhydrophobic surface for 5-fluorouracil encapsulation. Carbohydr. Polym. 2013, 98, 331-340. [CrossRef]

9. George, A.; Shah, P.A.; Shrivastav, P.S. Natural biodegradable polymers based nano-formulations for drug delivery: A review. Int. J. Pharm. 2019, 561, 244-264. [CrossRef] [PubMed]

10. Leite de Farias, A.; Meneguin, A.B.; da Silva Barud, H.; Brighenti, F.L. The role of sodium alginate and gellan gum in the design of new drug delivery systems intended for antibiofilm activity of morin. Int. J. Biol. Macromol. 2020, 162, 1944-1958. [CrossRef] [PubMed]

11. Prasher, P.; Sharma, M.; Mehta, M.; Satija, S.; Aljabali, A.A.; Tambuwala, M.M.; Anand, K.; Sharma, N.; Dureja, H.; Jha, N.K.; et al. Current-status and applications of polysaccharides in drug delivery systems. Colloid Interf. Sci. Commun. 2021, $42,1000418$. [CrossRef]

12. Sood, A.; Gupta, A.; Agrawal, G. Recent advances in polysaccharides based biomaterials for drug delivery and tissue engineering applications. Carboh. Polymer Tech. Appl. 2021, 2, 1000067. [CrossRef]

13. Alipour, S.; Mantaseri, H.; Tafaghodi, M. Preparation and characterization of biodegradable paclitaxel loaded alginate microparticles for pulmonary delivery. Colloids Surf. B Biointerf. 2010, 81, 521-529. [CrossRef]

14. Fabra, M.J.; Talens, P.; Chiralt, A. Effect of alginate and $\lambda$-carrageenan on tensile properties and water vapour permeability of sodium caseinate-lipid based films. Carbohydr. Polym. 2008, 74, 419-426. [CrossRef]

15. Shen, W.; Hsieh, Y.L. Biocompatible sodium alginate fibers by aqueous processing and physical crosslinking. Carbohydr. Polym. 2014, 102, 893-900. [CrossRef] [PubMed]

16. Afshar, M.; Dini, G.; Vaezifar, S.; Mehdikhani, M.; Movahedi, B. Preparation and characterization of sodium alginate/polyvinyl alcohol hydrogel containing drug-loaded chitosan nanoparticles as a drug delivery system. J. Drug Deliv. Sci. Technol. 2020, 56, 101530. [CrossRef]

17. Khuathan, N.; Pongjanyakul, T. Modification of quaternary polymethacrylate films using sodium alginate: Film characterization and drug permeability. Int. J. Pharm. 2014, 460, 63-72. [CrossRef]

18. Arica, B.; Calis, S.; Kas, H.S.; Sargon, M.F.; Hincal, A.A. 5-Fluorouracil encapsulated alginate beads for the treatment of breast cancer. Int. J. Pharm. 2002, 242, 267-269. [CrossRef] 
19. Agüero, L.; Zaldivar-Silva, D.; Pena, L.; Dias, M.L. Alginate microparticles as oral colon drug delivery device: A review. Carbohydr. Polym. 2017, 168, 32-43. [CrossRef] [PubMed]

20. Yuan, N.-N.; Li, S.-J.; Li, G.-Q. Sodium alginate coated mesoporous silica for dual bio-responsive controlled drug delivery. J. Drug Deliv. Sci. Technol. 2018, 46, 348-353. [CrossRef]

21. Gao, X.; Yu, Z.; Liu, B.; Yang, J.; Yang, X.; Yu, Y. A smart drug delivery system responsive to pH/enzyme stimuli based on hydrophobic modified sodium alginate. Eur. Polym. J. 2020, 133, 109779. [CrossRef]

22. Zhang, J.; Zhan, P.; Tian, H. Recent updates in the polysaccharides-based Nano-biocarriers for drugs delivery and its application in diseases treatment: A review. Int. J. Biol. Macromol. 2021, 182, 115-128. [CrossRef] [PubMed]

23. Kaygusuz, H.; Erim, F.B. Alginate/BSA/montmorillonite composites with enhanced protein entrapment and controlled release efficiency. Reacti. Funct. Polym. 2013, 73, 1420-1425. [CrossRef]

24. Sowjanya, J.A.; Singh, J.; Mohita, T.; Sarvanan, S.; Moorthi, A.; Srinivasan, N.; Selvamurugan, N. Biocomposite scaffolds containing chitosan/alginate/nano-silica for bone tissue engineering. Colloids Surf. B Biointerfaces 2013, 109, 294-300. [CrossRef]

25. Hambleton, A.; Voilley, A.; Debeaufort, F. Transport parameters for aroma compounds through i-carrageenan and sodium alginate-based edible films. Food Hydrocoll. 2011, 25, 1128-1133. [CrossRef]

26. Galus, S.; Lenart, A. Development and characterization of composite edible films based on sodium alginate and pectin. J. Food Eng. 2013, 115, 459-465. [CrossRef]

27. Pongjanykul, T.; Suksri, H. Nicotine-loaded sodium alginate-magnesium aluminium silicate (SA-MAS) films: Importance of SA-MAS ratio. Carbohydr. Polym. 2010, 80, 1018-1027. [CrossRef]

28. Abdollahi, M.; Alboofetileh, M.; Rezaei, M.; Behrooz, R. Comparing physical-mechanical and thermal properties of alginate nanocomposite films reinforced with organic and/or inorganic nanofillers. Food Hydrocoll. 2013, 32, 416-424. [CrossRef]

29. Alboofetileh, M.; Rezaei, M.; Hosseini, H. Effect of montmorillonite clay and biopolymer concentration on the physical and mechanical properties of alginate nanocomposite films. J. Food Eng. 2013, 117, 26-33. [CrossRef]

30. Cavallaro, G.; Gianguzza, A.; Lazzara, G.; Milioto, S.; Piazzese, D. Alginate gel beads filled with halloysite nanotubes. Appl. Clay Sci. 2013, 72, 132-137. [CrossRef]

31. Kurczewska, J.; Pecyna, P.; Ratajczak, M.; Gajecka, M.; Schroeder, G. Halloysite nanotubes as carriers of vancomycin in alginatebased wound dressing. Saudi Pharm. J. 2017, 25, 911-920. [CrossRef]

32. de Lima, H.H.; Kupfer, V.; Moisés, M.P.; Guilherme, M.R.; Rinaldi, J.D.C.; Felisbino, S.L.; Rubira, A.F.; Rinaldi, A.W. Bionanocomposites based on mesoporous silica and alginate for enhanced drug delivery. Carbohydr. Polym. 2018, 196, 126-134. [CrossRef] [PubMed]

33. Yang, L.; Ma, X.; Guo, N.; Zhang, Y. Preparation and characteristics of sodium alginate/Na(+) rectorite-g-itaconic acid/acrylamide hydrogel films. Carbohydr. Polym. 2014, 105, 351-358. [CrossRef] [PubMed]

34. Ionita, M.; Pandele, M.A.; Iovu, H. Sodium alginate/graphene oxide composite films with enhanced thermal and mechanical properties. Carbohydr. Polym. 2013, 94, 339-344. [CrossRef]

35. Nie, L.; Liu, C.; Wang, J.; Shuai, Y.; Cui, X.; Liu, L. Effects of surface functionalized graphene oxide on the behavior of sodium alginate. Carbohydr. Polym. 2015, 117, 616-623. [CrossRef] [PubMed]

36. Zhang, X.; Hui, Z.; Wan, D.; Huang, H.; Huang, J.; Yuan, H.; Yu, J. Alginate microsphere filled with carbon nanotube as drug carrier. Int. J. Biol. Macromol. 2010, 47, 389-395. [CrossRef]

37. Liakos, I.; Rizzello, L.; Bayer, S.I.; Paolo, P.; Cingolani, P.R.; Athanassiou, A. Controlled antiseptic release by alginate polymer films and beads. Carbohydr. Polym. 2013, 92, 176-183. [CrossRef]

38. Sookkasem, A.; Chatpun, S.; Yuenyongsawad, S.; Wiwattanapatapee, R. Alginate beads for colon specific delivery of selfemulsifying curcumin. J. Drug Deliv. Sci. Technol. 2015, 29, 159-166. [CrossRef]

39. Bera, H.; Ippagunta, S.R.; Kumar, S.; Vagala, P. Core-shell alginate-ghatti gum modified montmorillonite composite matrices for stomach specific flurbiprofen delivery. Mater. Sci. Eng. C 2017, 76, 715-726. [CrossRef] [PubMed]

40. Hasnain, M.S.; Nayak, A.K. Alginate-inorganic composite particles as sustained drug delivery matrices. In Applications of Nanocomposite Materials in Drug Delivery; Woodhead Publishing Series in Biomaterials; Woodhead Publishing: Sawston, UK, 2018; pp. 39-74. [CrossRef]

41. Tonnesen, H.H.; Karlsen, J. Alginate in Drug Delivery Systems. Drug Dev. Ind. Pharm. 2002, 28, 621-630. [CrossRef]

42. Depan, D.; Kumar, A.P.; Singh, R.P. Cell proliferation and controlled drug release studies of nanohybrids based on chitosan-g-lactic acid and montmorillonite. Acta Biomater. 2009, 5, 93-100. [CrossRef]

43. des Rieux, A.; Fievez, V.; Garinot, M.; Schneider, Y.J.; Préa, V. Nanoparticles as potential oral delivery systems of proteins and vaccines: A mechanistic approach. J. Control. Release 2006, 116, 1-27. [CrossRef] [PubMed]

44. Puttipipatkhachorn, S.; Pongjanyakul, T.; Priprem, A. Molecular interaction in alginate beads reinforced with sodium starch glycolate or magnesium aluminium silicate, and their physical characteristics. Int. J. Pharm. 2005, 293, 51-62. [CrossRef]

45. Jain, D.; Bar-Shalom, D. Alginate drug delivery systems: Application in context of pharmaceutical and biomedical research. Drug Dev. Ind. Pharm. 2014, 40, 1576-1584. [CrossRef]

46. Hu, L.; Sun, C.; Song, A.; Di, C.; Zheng, X.; Gao, Y.; Jiang, T.; Wang, S. Alginate encapsulated mesoporous silica nanospheres as a sustained drug delivery system for the poorly water-soluble drug indomethacin. Asian J. Pharm. Sci. 2014, 9, 183-190. [CrossRef]

47. Liao, Y.T.; Wu, K.C.W.; Yu, J. Synthesis of mesoporous silica nanoparticle-encapsulated alginate microparticles for sustained release and targeting therapy. J. Biomed. Mater. Res. Part B Appl. Biomater. 2013, 102B, 293-302. [CrossRef] [PubMed] 
48. Galarneau, A.; Barodawalla, A.; Pinnavaia, T. Porous clay heterostructures formed by gallery-templated synthesis. Nature 1995, 374, 529-531. [CrossRef]

49. Cecilia, J.A.; Garcia-Sancho, C.; Vilarassa-Garcia, E.; Jimenez-Jimenez, J.; Rodriguez-Castellon, E. Synthesis, characterization, uses and applications of porous clays heterostructures: A Review. Chem. Rec. 2018, 18, 1085-1104. [CrossRef]

50. Enotiadis, A.; Tsokaridou, M.; Chalmpes, N.; Sakavitsi, V.; Spyrou, K.; Gournis, D. Synthesis and characterization of porous clay-organic heterostructures. J. Sol-Gel Sci. Technol. 2019, 91, 295-301. [CrossRef]

51. Perdigon, A.C.; Li, D.; Pesquera, C.; Gonzalez, F.; Ortiz, B.; Aguado, F.; Blanco, C. Synthesis of porous clay heterostructures from high charge mic-type aluminosilicates. J. Mater. Chem. A 2013, 1, 1213-1219. [CrossRef]

52. Rubiyanto, D.; Prakoso, N.I.; Sahroni, I.; Nurillahi, R.; Fatimah, I. ZnO-porous clay heterostructures from saponite as green catalyst for citronelllal cyclization. Bull. Chem. Recat. Eng. Catal. 2020, 15, 137-145. [CrossRef]

53. Srithammaraj, K.; Magaraphan, R.; Manuspiya, H. Surfactant-templated synthesis of modified porous clay heterostructures (PCH). Adv. Mater. Res. 2008, 55-57, 317-320. [CrossRef]

54. Gârea, S.A.; Mihai, A.I.; Vasile, E.; Nistor, C.; Sârbu, A.; Mitran, R. Synthesis of new porous clay heterostructures: The influence of co-surfactant type. Mater. Chem. Phys. 2016, 179, 17-26. [CrossRef]

55. Polverejan, M.; Pauly, T.R.; Pinnavaia, T.J. Acidic porous clay heterostructures (PCH): Intragallery assembly of mesoporous silica in synthetic saponite clays. Chem. Mater. 2000, 12, 2698-2704. [CrossRef]

56. Mihai, A.I.; Garea, S.A.; Pandele, A.M.; Iovu, H. Properties of hybrid films based on poly(vinyl) alcohol and porous clay heterostructures. UPB Sci. Bull. 2017, 79, 58-66.

57. Mihai (Voicu), A.I.; Garea, S.A.; Eugeniu, V.; Nistor, L.C.; Iovu, H. Functionalization of porous clay heterostructures with silane coupling agents. Mater. Plast. 2017, 54, 341-344. [CrossRef]

58. Palkova, H.; Madejova, J.; Zimowska, M.; Sewicka, E.M. Laponite-derived porous clay heterostructures: II. FTIR study of the structure evolution. Microporous Mesoporous Mater. 2010, 127, 237-244. [CrossRef]

59. Wang, Y.; Su, X.; Xu, Z.; Wen, K.; Zhang, P.; Zhu, J.; He, H. Preparation of surface-functionalized porous clay heterostructures via carbonization of soft-template and their adsorption performance for toluene. Appl. Surf. Sci. 2016, 363, 113-121. [CrossRef]

60. Cecilia, J.A.; Garcia-Sancho, C.; Franco, F. Montmorillonite based porous clay heterostructures: Influence of Zr in the structure and acidic properties. Microporous Mesoporous Mater. 2013, 176, 95-102. [CrossRef]

61. Kooli, F.; Liu, Y.; Hbaieb, K.; Al-Faze, R. Characterization and catalytic properties of porous clay heterostructures from zirconium intercalated clay and its pillared derivatives. Microporous Mesoporous Mater. 2016, 226, 482-492. [CrossRef]

62. Bunnak, N.; Laoratanakul, P.; Bhalla, A.S.; Manuspiya, H. Surface-Modified Porous Clay Heterostructure Synthesized by Introduction of Cationic Ions: Effects on Dielectric Behavior. Feeoelectrics 2014, 473, 187-197. [CrossRef]

63. Chotiradsirikun, S.; Guo, R.; Bhalla, A.S.; Manuspiya, H. Nouvel synthesis route of porous clay heterostructures via mixed surfactant template and their dielectric behavior. J. Porous Mater. 2021, 28, 117-178. [CrossRef]

64. Al Dmour, H.; Kooli, F.; Mohmoud, A.; Liu, Y.; Popoola, S.A. Al and Zr porous clay heterostructures as removal agents of basic blue-41 dye from an artificially polluted solution: Regeneration properties and batch design. Materials 2021, 14, 2528. [CrossRef]

65. Kooli, F.; Liu, Y.; Hbaieb, K.; Al-Faze, R. Factors that affect the thermal stability and properties of Zr-porous clay heterostructures. J. Therm. Anal. Calorim. 2016, 126, 1143-1155. [CrossRef]

66. Sanchis, R.; Cecilia, J.A.; Soriano, M.D.; Vázquez, M.I.; Dejoz, A.; Nieto, J.M.L.; Castellón, E.R.; Solsona, B. Porous clays heterostructures as supports of iron oxide for environmental catalysis. Chem. Eng. J. 2018, 334, 1159-1168. [CrossRef]

67. Vilarrasa-Garcia, E.; Cecilia, J.A.; Azevedo, D.C.S.; Cavalcante, C.L., Jr.; Rodrigues-Castellon, E. Evaluation of porous clay heterostructures modified with amine species as adsorbent for the $\mathrm{CO}_{2}$ capture. Microporous Mesoporous Mater. 2017, 249 , 25-33. [CrossRef]

68. Aguiar, J.E.; Cecilia, J.A.; Tavares, P.A.S.; Azeveda, D.C.S.; Rodriguez Castellon, E.; Lucena, S.M.P.; Silva Junior, I.J. Adsorption study of reactive dyes onto porous clay heterostructures. Appl. Clay Sci. 2017, 135, 35-44. [CrossRef]

69. Tassanapayak, R.; Magaraphan, R.; Manuspiya, H. functionalized porous clay heterostructures for heavy metal adsorption from wastewater. Adv. Mater. Res. 2008, 55-57, 617-620. [CrossRef]

70. Yuan, M.; Su, Y.; Deng, W.; Zhou, H. Porous clay heterostructures (PCH) modified with copper ferrite spinel as catalyst for SCR of NO with C3H6. Chem. Eng. J. 2019, 375, 122091. [CrossRef]

71. Soriano, M.D.; Cecilia, J.A.; Natoli, A.; Jimenez-Jimenez, J.; Nieto, J.M.L.; Rodriguez-Castellon, E. Vanadium oxide supported on porous clay heterostructure for the partial oxidation of hydrogen sulphide to sulfur. Catal. Today 2015, 254, 36-42. [CrossRef]

72. Chmielarz, L.; Kowalczyk, A.; Skoczek, M.; Rutkowska, M.; Gil, B.; Natkanski, P.; Radko, M.; Motak, M.; Debek, R.; Ryczkowski, J. Porous clay heterostructures intercalated with multicomponent pillars as catalysts for dehydration of alcohols. Appl. Clay Sci. 2018, 160, 116-125. [CrossRef]

73. Kooli, F. Porous clay heterostructures (PCHs) from Al13-intercalated and Al13-pillared montmorillonite: Properties and heptane hydro-isomerization catalytic activity. Microporous Mesoporous Mater. 2014, 184, 184-192. [CrossRef]

74. Gârea, S.A.; Mihai, A.I.; Ghebaur, A.; Nistor, C.; Sârbu, A. Porous clay heterostructures: A new inorganic host for 5-fluorouracil encapsulation. Int. J. Pharm. 2015, 491, 299-309. [CrossRef]

75. Garea, S.A.; Mihai, A.I.; Ghebaur, A. Hybrid films based on sodium alginate and porous clay heterostructures. Mater. Plast. 2015, $52,275-280$. 
76. Son, Y.; Kim, T.-H.; Kim, D.; Hwang, Y. Porous clay heterostructures with alginate encapsulation for toluene removal. Nanomaterials 2021, 11, 388. [CrossRef]

77. Chiewa, C.S.C.; Poh, P.E.; Pasbakhsh, P.; Tey, B.T.; Yeoh, H.K.; Chan, E.S. Physicochemical characterization of halloysite/alginate bionanocomposites hydrogel. Appl. Clay Sci. 2014, 101, 444-454. [CrossRef]

78. Xiao, Q.; Gu, X.; Tan, S. Drying process of sodium alginate films studied by two-dimensional correlation ATR-FTIR spectroscopy Food Chem. 2014, 164, 179-184. [CrossRef]

79. Kang, H.; Shu, Y.; Li, Z.; Guan, B.; Peng, S.; Huang, Y.; Liu, R. An effect of alginate on the stability of LDH nanosheets in aqueous solution and preparation of alginate/LDH nanocomposites. Carbohydr. Polym. 2014, 100, 158-165. [CrossRef] [PubMed]

80. Abou Taleb, M.F.; Hegazy, D.E.; Ismail, S.A. Radiation synthesis, characterization and dye adsorption of alginate-organophilic montmorillonite nanocomposite. Carbohydr. Polym. 2012, 87, 2263-2269. [CrossRef]

81. Zhang, H.; Shi, Y.; Xu, X.; Zhang, M.; Ma, L. Structure regulation of bentonite-alginate nanocomposites for controlled release of imidacloprid. ACS Omega 2020, 5, 10068-10076. [CrossRef]

82. Reddy, O.S.; Subha, M.C.S.; Jithendra, T.; Madhavi, C.; Rao, K.C. Curcumin encapsulated dual cross linked sodium alginate/montmorillonite polymeric composite beads for controlled drug delivery. J. Pharm. Anal. 2021, 2, 191-199. [CrossRef]

83. Alcantara, A.C.S.; Aranda, P.; Darder, M.; Ruiz-Hitzky, E. Bionanocomposites based on alginate-zein/layered double hydroxide materials as drug delivery system. J. Mater. Chem. 2010, 20, 9495-9504. [CrossRef]

84. Zang, J.P.; Wang, Q.; Xie, X.L.; Li, X.; Wang, A.Q. Preparation of swelling properties of $\mathrm{pH}$-sensitive sodium alginate/layered double hydroxides hybrid beads for controlled release of diclofenac sodium. J. Biomed. Mater. Res. B Appl. Biomater. 2010, 92, 205-214. [CrossRef] [PubMed] 